\title{
CHRONICLING NATIONAL ASSEMBLY COMMITTEES AS MARKERS OF INSTITUTIONAL CHANGE
}

\author{
Authors: \\ Dr. Diana S. Stirbu (lead author) \\ Senior Lecturer in Public Administration \\ London Metropolitan University \\ 166-220 Holloway Road, London N7 8DB \\ Tel: + 44 (0) 2071332150 \\ Email: d.stirbu@londonmet.ac.uk
}

\author{
Laura McAllister \\ Professor of Public Policy and the Governance of Wales, \\ Cardiff University, \\ Wales Governance Centre, \\ 21 Park Place, \\ Cardiff, CF10 3DU, \\ Tel: +44 2920875426 \\ Email: McAllisterL3@cardiff.ac.uk
}

\footnotetext{
'This is an Author's Original Manuscript of an article published by Taylor \& Francis Group in The Journal of Legislative Studies on 13 $^{\text {th }}$ September 2018, available online: https://doi.org/10.1080/13572334.2018.1516606'
}

Page 1 


\begin{abstract}
This article examines changes to the National Assembly for Wales committees and how they act as markers that help explain the dynamics of a significant and contemporaneous constitutional journey. It uses as its backdrop recent constitutional and political change in the UK, particularly that initiated by devolution. Uniquely, we draw upon management theory as well as political science to explain why changes in the focus, identity and profile of Assembly committees represent significant markers or reflectors of constitutional shifts. We suggest that examining key components within the internal architecture of parliaments at different stages of development offers an additional and complementary level of institutional analysis. Our review of the Assembly committees reveals that they have reflected the pace and shape of change in Welsh devolution, and that shifts in their profile and operation offer another insight into devolution, whilst also reflecting wider institutional and political change.
\end{abstract}

\title{
Keywords
}

Institutional change, devolution, parliament, committees, Wales

Page 2 


\section{CHRONICLING NATIONAL ASSEMBLY COMMITTEES AS MARKERS OF INSTITUTIONAL CHANGE}

\section{Introduction}

Renewed interest in the operation and modernisation of parliaments, set alongside the current unprecedentedly fluid constitutional politics in the United Kingdom, provides an opportunity to consider alternative ways of chronicling institutional change within parliamentary settings and of assessing the role of parliamentary committees in absorbing and reflecting constitutional dynamics. This article explores the role of key components within the internal architecture of the National Assembly for Wales [Assembly], one of UK's devolved legislatures, in mapping and marking some significant chapters in its institutional development, a journey that has been precipitated by a heavy constitutional flux since 1999 when the Assembly was established.

Much of the literature around constitutional change explores challenges in reconciling customary constitutional principles - parliamentary sovereignty, in particular - with the practice, politics and judicial implications of devolution and Europeanisation (Gifford 2010; Carter, 2013; Elcock and Keating, 2013; Bradbury and Mawson 2014; Elliott 2015). The redefinition of the citizen-parliament proxy has also attracted some interest in the context of reconnecting citizens with the political process (Leston-Bandeira 2012, 2016), and the use of referenda for dealing with constitutional issues (Curtice 2013; Laycock 2013). Yet, how parliamentary institutions specifically absorb these high level constitutional shifts internally has been less explored.

The House of Lords Select Committee on the Constitution modelled its own definition of the constitution as: 'the set of laws, rules and practices that create the basic institutions of the state, and its component and related parts, and stipulate the powers of those institutions and the 
relationship between the different institutions and between those institutions and the individual' (House of Lords, 2001/2). From a territorial perspective, constitutional change in Wales includes any transformation or adaptation of the constituent framework supporting the post 1999 polity: devolved powers and competencies, power structures, the relationships between them, the citizen-Assembly link. We use this as a mechanism for distinguishing between institutional and constitutional change and for determining where institutional change instigates constitutional shifts and vice versa, when constitutional shifts lead to dramatic institutional reconfiguration.

Given the UK predilection for outsourcing constitutional deliberation to independent or Royal Commissions (McAllister 2005, McAllister and Stirbu 2008), the literature (in the UK) focusing on the specific contributions made by parliamentary committees to institutionalising and stimulating constitutional change is rather scarce, as the focus lies predominantly on their pre-legislative and legislative scrutiny roles. Analysis of institutional modernisation at Westminster, focused on strengthening select committees' effectiveness vis a vis scrutiny, legislative efficiency, and policy contribution is extremely useful (Norton 2000; Flinders 2002; Brazier et al 2005; Russell 2011). Griffiths and Evans (2013) offer some insight into the Commons Welsh Affairs Select Committee's role in constitutional development and in devolving of further powers to Wales. Outside Westminster, analysis of Scottish, Welsh and Northern Irish committees is limited to studies of operation, participative nature, scrutiny capacity and policy influence (see Arter 2004, 2006; Cairney 2006; McAllister and Stirbu 2007, McLaverty and McLeod 2012; Cole 2014; Cole and McAllister 2015). Stirbu (2009) explores how constitutional dynamics in Wales have shaped the institutional development of the National Assembly and opens the debate around the extent to which institutional change itself precipitated constitutional shifts in Wales.

More broadly, the rich body of literature linking parliamentary modernisation to strengthening committee systems tends to focus mostly on legislation or oversight committees, ignoring other 
types (i.e. ad-hoc, procedures, finance) (see Longley eds. 1994; Dorring ed. 1995; Longley and Agh eds. 1997; Longley 2012). Most functionalist studies develop useful comparators of parliamentary practice, measures of strength, influence, and committee cohesion (Hazan 2003), yet, they tend to assume a high degree of institutional maturity and optimality (Strom 1998). This seems questionable in the case of small or newly established institutions - such as the National Assembly -, where size is an important constraining factor.

Similarly, new institutionalists' concern with legislative organisation (Mattsom and Strom 1995) places committee systems at the heart of parliamentary deliberative or legislative processes (Dorring 2001; Pollack 2003; Arter, 2006), yet the agency perspective underpinning such approaches gives prominence to political parties as the principal form of parliamentary organisation, whilst regarding committees as mere extensions of political parties (Damgaard 1995; Kim and Loewenberg 2005) - a significant limitation in our opinion. Studies of committees' cohesion, autonomy and counterweighting government party domination (Drewry 1985; Kelly 2013) can offer better balance.

Our study addresses the existing gaps and limitations of the scholarship to date by 1) expanding analysis to a broader range of committees, some with administrative or internal corporate governance roles and which, we argue, are equally critical in shaping our understanding of how institutions behave in changing constitutional contexts; and 2) by chronicling committees' contributions to institution building using a holistic and more forensic analysis of the institutionalisation process. Our case study on the Assembly committees is justified by the fact that Wales has experienced a steady accrual of powers and a rapidly shifting constitutional terrain since devolution, reflected in its internal architecture and operation over the last 20 years. Naturally, this has had a direct effect on its committee system, seen as the "engine room" and the "heartbeat" of the Assembly. Therefore, the Assembly's institutional journey provides fruitful 
terrain to test our central contention that committees are valuable reflectors that mark the change process.

The objectives of this article are four fold. First, we chronicle the evolution of the Assembly's committee system, mapping it across the four stages in Wales's constitutional settlement to date. Second, we investigate how the committee system has encapsulated devolution's most prominent rhetoric - that of closer engagement with the citizens. Third, we consider committees' usefulness in understanding Wales's constitutional development by exploring the extent to which constitutional affairs and procedural change have been embedded in permanent structures and processes within the Assembly. Finally, we investigate the extent to which the committee system has matured and achieved stable patterns of organisation, behaviour, and autonomy.

Our rationale for focusing on parliamentary committees' specific contribution to institution-building has been stimulated on the one hand by the significant constitutional flux in the UK and, on the other hand, by the way in which shifts in the internal architecture of parliamentary institutions act as levers for better understanding wider change. Furthermore, the devolution of power within the UK has reignited interest in different parliamentary structures that operate adjacently. Given the Assembly committees' propensity to absorb and engineer change, we were encouraged to adopt a more holistic approach to understanding institutional change, especially when this is prompted by rapid constitutional shifts. The subsidiary value of this is that it also generates renewed analysis of committee systems themselves that extends beyond their traditional functions in legislative scrutiny and oversight of government.

\section{Approach}

The article draws out specific evidence from over 12 years' research by the authors on devolution in Wales that explored key aspects of the Assembly's development as a parliamentary 
institution. Within this, a wide range of ethnographic and documentary methods has been employed to investigate institutional shifts. Between 2004 and 2016, we conducted over 100 interviews with politicians, senior officials and staff, and constitutional experts. We have also conducted a focus group with subject committee clerks exploring lessons from early experimentation with public engagement. Further participant observation between 2006 and 2011 provided unique insight into how the Assembly managed the transition from a corporate body to a parliamentary structure. We also draw on direct and active participation in some of the Assembly's major institutional transformations in advisory capacities through expert groups, panels and commissions. Supporting this is documentary research including extensive analysis of committees' operational documents (minutes, agendas, reports).

The specific theoretical approach we adopt is important as it blends elements of political theory with management analysis to create a unique framework within which to evaluate the Assembly committees' overall contribution to institutional development. Drawing on institutional theory, our starting assumption is that new political institutions exhibit an inherent volatility at both structural and operational level (Huntington 2006). Our interest is in exploring and understanding the processes by which new institutions become stable, valued and predictable. The measure of parliamentary institutionalisation is given by the level of functional and organisational differentiation of the committee system from the wider political environment and the extent to which committee practice becomes established and predictable (Olson and Crowther 2002).

We were guided by a vast body of literature focused on the institutionalisation of parliaments (Paterson and Copeland 1994; Norton 1998), especially from the perspective of regime change in Eastern Europe (Agh, 1998; Olson and Crowther 2002). This is particularly helpful because it accounts for highly dynamic constitutional contexts. The UK's devolved legislatures featured a significant degree of institutional volatility in their early years. They arguably had less 
institutional legacy than the transitional legislatures in Eastern Europe and benefited from a relative blank-slate which permits certain experimentation to take place (McAllister and Stirbu 2007a and b). However, just as within the new democratic legislatures in Eastern Europe, committees are nested within parliaments and contribute to their development and maturing process (Olson and Crowther 2002).

Devolution, although evidently not as dramatic a transition as from an oppressive regime to a democratic one, does challenge at least some of the tenets of the UK constitution (House of Lords, 2011) by creating a multilevel system of governance: from centrist to more decentralised policy-making, from a majoritarian politics to a more pluralist one (McAllister and Kay 2010) and from an elitist to a more participatory and inclusive political culture. In the UK, these were articulated as the very goals of devolution -a process designed to close the gap between government and the people.

Then, borrowing from management theory, we draw upon approaches that focus on the strategic positioning of organisations within their wider industry for the purpose of gaining competitive advantage (Porter 1996), in other words exploring organisations' strategic fit within their broad environments (societal, sectoral, organisational). The establishment and development of political institutions also raises questions around the logic and appropriateness of institutional design and change (Olsen and March 2004) and, in so far as competitive advantage needs conceptual realignment, there is a strong case for parliaments considering positioning strategies within ever complex, multilevel systems, where public profile and trust, for instance, are crucial to legitimacy, and their bargaining power is essential for effective scrutiny.

We explore new ground by employing a different interpretation of the Aston Matrix (Table 1), a management tool developed as a positioning and sense making device that helps organisations scan their near and far environments and make sense of factors impacting them (Brown and 
Osbourne 2012). Management analysis is generally concerned with future trends. However, in this article, we adopt a more retrospective approach. The validity of the Aston Matrix, as applied here, is that it allows us to analyse committees' contributions at multiple levels: societal, constitutional and organisation level, by identifying some of the most important determinant of change, at each level, along their institutional journey.

Given the level of political and administrative flux around Welsh devolution, it was important that we took an expansive approach to committees, by including subject, standing as well as ad-hoc committees, and explore their role in the management, administration and repeated reconfiguration of the institution, a contribution that, to date, has remained largely undocumented in academic studies and only loosely conceptualised in theory.

Management literature uses a traditional, yet limiting classification of the determinants of change: political, social, economic, and technological trends, usually. However, we regard institutional change as extremely complex and we are interested in identifying the strongest proxy through which change is channelled at each level.

Devolution stimulated deep transformations at every level in the Assembly's environment. At societal (meta) level, we position committees, as our principal focus of analysis, within the new deliberative space created by devolution. Public engagement, encompassing anything from outreach, informing, and involving the public, to maintaining an outward-looking and visible public profile, is identified early as the main proxy through which the Assembly has both absorbed and sought to deliver upon the devolution rhetoric, and established itself as a legitimate actor representing the people of Wales. This legitimacy is somewhat fragile however, as discussed by Scully and Wyn Jones (2015). We examine committees' roles in institutionalising the relationship between the public and the Assembly and document the evolution of mechanisms for engagement, assessing the extent to which these have become standardised.

Page 9 
At sectoral (macro) level, we identify institutional development, especially of constitutional significance, as the proxy for examining to what extent the Assembly has acquired value, predictability and resilience in the face of political change. We focus on investigating committees' contributions to informing some of the wider constitutional debates around the Assembly's structure and status. At micro (organisational) level, we focus on the stability and predictability of the committee system as a whole, and in particular on committees' autonomy and scrutiny capacity.

Table 1 - The Aston Matrix:

\begin{tabular}{|l|c|c|c|}
\hline Level & Meta & Macro & Micro \\
\hline $\begin{array}{l}\text { Dominant Factors } \\
\text { stimulating institution } \\
\text { building }\end{array}$ & Public engagement & & \\
\cline { 2 - 4 } & & Constitutional affairs & \\
\cline { 2 - 4 } & & & $\begin{array}{l}\text { Committee system } \\
\text { institutionalisation }\end{array}$ \\
\hline
\end{tabular}

Positioning these elements on the three distinctive levels of the Aston Matrix that incorporate the Assembly's near and far environments helps gauge the committees' fullest contributions to constitutional and organisational change and to the wider democratic process in Wales. Furthermore, this helps test the solidification and maturing of organisational practice within the institution. 


\section{Assembly committees and constitutional arrangements}

The Assembly's relatively short existence (currently half way into its fifth term) can be punctuated by three institutional interregnums, distinguished as follows: the corporate body period (1999-2007) under the constitutive Government of Wales Act 1998; the interim constitution period (2007-2011) under the Government of Wales Act 2006; the primary (conferred) powers period, following the 2011 referendum ${ }^{1}$.

Table 2 - The evolution of the Assembly committee system

\begin{tabular}{|c|c|c|c|c|}
\hline & 1st Assembly & 2nd Assembly & 3rd Assembly & 4th Assembly \\
\hline Stage & \multicolumn{2}{|c|}{ corporate body } & interim constitution & primary powers \\
\hline $\begin{array}{l}\text { Committee system } \\
\text { (number of } \\
\text { committees) }\end{array}$ & $\begin{array}{c}\text { Subject Committees (7) } \\
\text { Regional Committee (4) } \\
\text { Standing Committees (7) } \\
\text { Ad-hoc (2) - } 20\end{array}$ & $\begin{array}{l}\text { Subject Committees (5) } \\
\text { Regional Committee (7) } \\
\text { Standing Committees (7) } \\
\text { Ad-hoc (13/14) - } 32\end{array}$ & $\begin{array}{l}\text { Legislation Committees (5) } \\
\text { Scrutiny Committees (6) } \\
\text { Other /Standing Committees (9) } \\
\text { Other / Non-permanent (2) - } 22\end{array}$ & $\begin{array}{l}\text { Scrutiny Committees (5) } \\
\text { Other / Standing (6) } \\
\text { Other Non-Permanent (2) } \\
\text { Total: } 13\end{array}$ \\
\hline $\begin{array}{l}\text { Scrutiny / } \\
\text { Legislation roles }\end{array}$ & \multicolumn{2}{|c|}{$\begin{array}{c}\text { Dual role Subject Committees: Policy development } \\
\text { scrutiny of government side } \\
\text { Consider secondary legislation }\end{array}$} & $\begin{array}{c}\text { Separate: } \\
\text { Legislation Committees: consider } \\
\text { LCO and Assembly Measures } \\
\text { Subject based Committees: } \\
\text { scrutinise government }\end{array}$ & $\begin{array}{c}\text { Dual role Subject Committees } \\
\text { consider legislation, scrutinise } \\
\text { government }\end{array}$ \\
\hline Prescription & \multicolumn{2}{|c|}{$\begin{array}{l}\text { High: type (Subject, Regional, Audit, Secondary } \\
\text { Legislation) } \\
\text { Membership and size: strict (d'Hondt) + ministerial } \\
\text { membership in Subject Committees }\end{array}$} & \multicolumn{2}{|c|}{$\begin{array}{c}\text { Relaxed: Standing Order to decide committee structure } \\
\text { Prescribed: Audit }\end{array}$} \\
\hline Committee size & \multicolumn{2}{|c|}{ Prescribed: 8-11 across all (except ad-hoc-5) } & \multicolumn{2}{|c|}{ Flexible: from 4 to 10} \\
\hline $\begin{array}{l}\text { Committee } \\
\text { Portfolios }\end{array}$ & \multicolumn{2}{|c|}{ mirror executive portfolios } & \multicolumn{2}{|c|}{ cross cutting } \\
\hline Legislative Initiative & \multicolumn{2}{|c|}{ only policy development } & \multicolumn{2}{|c|}{ can initiate legislation } \\
\hline
\end{tabular}

\footnotetext{
${ }^{1}$ A fourth stage - based on a reserved powers model - has emerged following the Wales Acts 2014 and 2017.
} 
Under the corporate body model (GoWA 1998, S.1 ss.2), the Assembly committees reflected to an extent, both the constitutional limitations of Welsh devolution and the grand aspirations in relation to inclusiveness. There were some unusual prescriptions on committees number, types, and membership rules. The most significant of these was that the executive secretary (later known as 'minister') be a member of the subject committee reviewing their relevant portfolio (GoWA 1998, S. 57 ss. 4). This brought obvious benefits around information sharing across the committee, but attracted heavy criticism for hindering the development of a stronger scrutiny culture (Richard Commission 2004; McAllister and Stirbu 2007a)

The interim constitution stage, framed by the Government of Wales Act 2006, marks the formal separation of executive and enhanced legislative functions of the Assembly, and signalled a move to a less prescriptive framework with regards to the Assembly's internal organisation (GoWA 2006, s.28 \& 29). However, legislative powers were only granted in two stages. In the interim stage, powers were enhanced by Assembly Measures ${ }^{2}$ in competence areas (Schedule 5 of GoWA 2006, S.95) and by possibly amending Schedule 5 via Legislative Competence Orders (LCO), which required the approval of the Assembly and of both Houses of Parliament. A significant re-configuration of the committee system occurred, separating legislation and scrutiny roles of committees. Legislation committees were initially set-up as ad-hoc, along the lines of Westminster public bill committees, and later replaced by five permanent legislation committees, with no particular thematic specialisation, other than one being exclusively dedicated to members' proposed legislation.

The next stage, enshrined in Part IV of the 2006 Act, set out the steps towards full primary legislative powers in fields of devolved competence, conditional on support in a referendum. The referendum in March 2011 saw 65.35\% vote in favour of the move. Since 2011, the Assembly's powers, structure and operations define it as a parliamentary body, on similar footing with the

\footnotetext{
${ }^{2}$ Similar to Acts of Parliament
} 
other UK devolved legislatures. The more streamlined legislative process and a more strategic organisational environment following the establishment of the Assembly Commission, created radically different conditions for the committee system aspiring to promote a connected approach to legislation and scrutiny (Assembly Commission 2013). The cross cutting committee portfolios were carried over and expanded, and legislative duties were once again blended in with scrutiny, resulting in five committees covering both policy and legislation alongside a series of other relatively well-established standing committees, some of which with important institutional legacy (i.e. Business, Public Accounts or Standard of Conduct).

\section{Aston Matrix applied}

Meta-level: Committees' public engagement

Our analysis started by assessing committees' contributions to institutionalising public engagement through the 'parent' organisation. We reviewed formal consultation mechanisms (oral and written evidence gathering) as well as informal engagement practices (direct engagement with stakeholders via informal meetings, focus and reference groups, outreach via off site visits, surveys, rapporteurs) and ICT facilitated engagement (online discussion forums, social media use, video engagement). These initiatives help expose the qualitative and quantitative relationship between the Assembly and the public, which is integral to the devolution project given the original goals around inclusiveness, openness, and democratic renewal (against a backdrop of perceived limited legitimacy given the 1997 Referendum saw just $50.3 \%$ of voters support the establishment of an Assembly).

As criteria for institutionalisation, Olson and Crowther (2002) single out organisational and functional differentiation from the environment, and the use of universalistic rather particularistic standards. Organisational and functional differentiation refers to the existence of distinctive institutional structures, process and resources channelled towards supporting, in our case, the 
Assembly's engagement practices. The evolution of the Welsh committee system shows evidence of all three criteria being met (or partially met) in terms of entrenching public engagement into committee operation in a stable and predictable way.

We distinguish two stages here. The first appears counterintuitive and is underpinned by features of the original corporate body, namely a lack of clear legislative focus which allowed committees to experiment with policy development instead, and a lack of overarching corporate strategy, which meant committees developed their own ways of direct engagement with stakeholders and the public. Most of this experimentation was dominated by informal practices and by particularistic rather than universal standards.

In one focus group ${ }^{3}$, subject committee clerks highlighted the limited formalisation and standardisation of public consultations during the first two terms. The relative informality of engagement mechanisms, allegedly facilitating smoother access to committees - as one chief executive of a prominent civil society organisation mentioned - comes more from the lack of institutional and procedural precedent, rather than from a calculated attempt to innovate. Committee clerks considered that to some extent these limitations actually worked to the Assembly's benefit in the process of institutional learning, as a number of engagement mechanisms were established and tested: formal consultation exercises, reference groups, off-site visits, rapporteurs. Nonetheless, the frenzy of consultation initiated by Assembly committees as well as by the government side arguably left the Welsh civic society drained and fatigued (Chaney and Fevre, 2001; Day 2006). Questions about the depth of consultation exercises in the early years of the Assembly led to attempts to diversify mechanisms to reach out to the general public more widely. Yet, as the participants in our focus group reveal, some of the more expansive engagement exercises in the second term struggled, at times, with the overall quality of the evidence gathered.

\footnotetext{
${ }^{3}$ Conducted in 2006
} 
The second stage took place within the more strategically-oriented institutional climate post 2007 under the Assembly Commission's leadership, which put public engagement and engagement with young people at the heart of its first comprehensive strategies (Assembly Commission 2007, 2011) and changed the organisation and management of the committee support services (Assembly Commission, 2013).

At committee level, the citizen-Assembly link has been enhanced by the introduction of the petitions process ${ }^{4}$, and the establishment of a Petitions Committee. As one of the most common forms of political engagement of the last few decades (Hansard Society 2010), yet clearly not a panacea for successfully effecting political or policy change (Hough 2012), the Assembly's petitions system is, nonetheless, evidence of organisational and functional differentiation of Assembly's engagement role.

The petition system followed the more established and advanced Scottish Parliament petitions substantive model, making it easily accessible to the public and, through visible presence and outreach, encouraging citizens to engage. The Assembly Petitions Committee can solicit action from relevant government Ministers, conduct its own inquiries, or refer the matter to other committees, whilst continuing to monitor progress. There is some evidence that petitioning has been actively pursued by the Welsh public, with more than 700 petitions received by February 2017, out of which 311 were completed. Assessing the real and direct impact of petitioning beyond entrenching the citizen-Assembly relationship is problematic and beyond the scope of our work. However, we are interested in the institutional nestedness of the petition system within the Assembly. The 2016 review of the petition system suggests that, whilst certain reforms are necessary to improve accessibility and overall impact of petitioning (Petitions Committee 2016), the system has achieved a certain degree of stability and predictability.

\footnotetext{
${ }^{4}$ paper petitions in 2007 and e-petitions in 2008
}

Page 15 
Outside the petitions system, committees have formalised and standardised the consultation processes within their policy inquiry work. This follows a familiar template: committees issue consultation letters; individuals, groups and organisations respond; committees invite oral evidence from witnesses and experts; deliberation and reports are published. Since 2007, all committees -without exception- have followed this pattern proving that 'consultation' has become a universal standard of formal engagement. There are of course variations in the scope of consultations, as our data from the fourth term illustrates.

Figure 1 - Committee Public Engagement in Policy Enquiries in the 4th Assembly- to replace existing figure

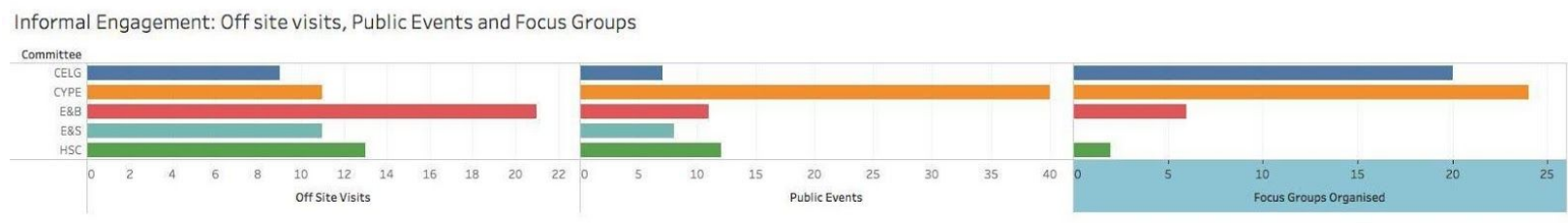

Wider engagement: Surveys

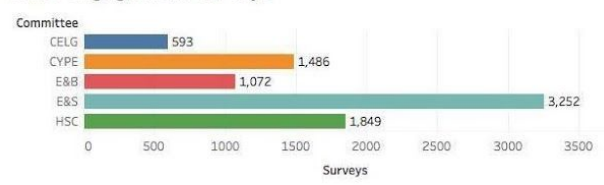

Online/Video Engagement

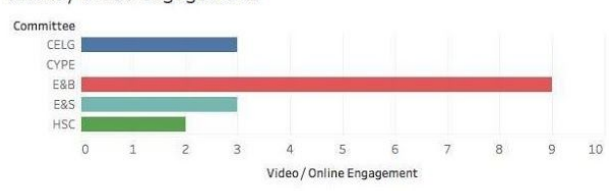

Formal Consultation: Written and Oral Evidence

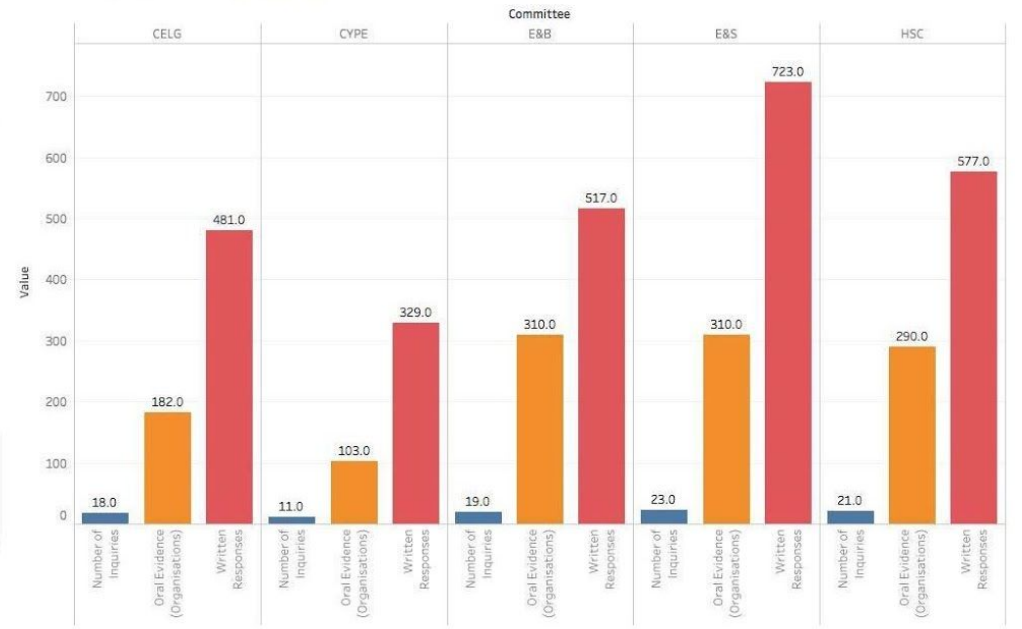


Qualitative improvements in the process include better referencing of the evidence received, alongside with full publication of the responses and of evidence sessions recordings. Some of our interviews in 2015/16 suggested this was partly attributed to feedback from organisations that saw little acknowledgement and 'influence' of their contributions. Rumbul (2016) challenges the representativeness of this formal engagement process pointing to the disproportionately low number of women appearing in front of committees in oral evidence sessions.

Beyond this formal engagement with the usual suspects -civil society organisations, local authorities, business and individual experts- committee clerking and support teams have sought to reach out to the broader public. Enhancing informal as well as online engagement has been one of the strategies pursued in the third and fourth terms. Our interviews reveal that the type of policy inquiry (follow ups, snap scrutiny of government policy, broader reviews) will however determine the scale and nature of the engagement. This may explain variations in the way committees seek to engage the public outside the formal call for evidence and witnesses. Another explanation, as some of our interviewees point, is the variable level of enthusiasm at the level of the committee chair and clerking team.

The integration and co-location of support services for committees (clerking, research, legal advice, communication and outreach) in the fourth term (Assembly Commission 2013) created the conditions for further customisation and diversification of direct and indirect engagement, especially with regards to surveys, facilitating focus groups on given themes, creating and mediating online discussion forums and producing video engagement tools, feeding back into the committees' inquiry work. The advanced use of information and communication technology (webcasting and video engagement) enhanced accessibility to committees of remote witnesses and of the general public in general. This suggests that committees internalised some of the devolution rhetoric by entrenching accessibility and transparency in their day-to-day operation. 
Our analysis reveals a conscious effort made by committees towards a qualitative (i.e. avoiding anecdotal evidence, reaching out beyond the usual suspects) and quantitative (i.e. diversifying channels and mechanisms of engagement) improvement of the citizen-Assembly relationship. This process, at first informal, unidirectional, lacking standardisation and clarity of purpose, gradually matured in the third and fourth terms, whilst also being incorporated at strategic level. An important shift has been clarifying the purpose public engagement serves at institutional and committee level (Assembly Commission 2011, 2013).

The evidence presented here points to a higher degree of functional and organisational differentiation of public engagement within the committees system. This has been achieved first by means of the Petitions Committee, a structure that shows elements of stability and continuity, and second by the Assembly Commission's contribution to embedding public engagement within institutional strategy.

Macro-level: Committees as agents of organisational change and reflectors of constitutional change

The next level of analysis explores Assembly's positioning within the devolved constitutional context. We identified the institutionalisation of constitutional affairs and procedural change as the main proxy by which the Assembly evolved from a limited corporate body structure towards an established UK legislature. By constitutional affairs, we mean anything from influence over, or decision upon, the Assembly's internal operation and structure, scrutiny of external constitutional decisions impacting on Wales, triggering and shaping constitutional deliberations. We take the view that some institutional changes within the Assembly have constitutional significance and so treat them as such. 
Constitutional debate intensified with the publication of the Better Governance for Wales White Paper 2005, and the subsequent Government of Wales Bill 2006, which proposed the formal separation between the executive and legislative arms of the Assembly - one of the landmarks of in Wales' constitutional development. By the time the separation process was launched (end of 2015), there had been limited institutionalisation of constitutional affairs within the Assembly, bar from the Welsh Assembly Government's own constitutional affairs unit, itself a non-permanent feature.

The process preparing the grounds for the administrative, political and legal separation was operationalised by a series of ad hoc committees. In May 2006, in response to provisions in the Government of Wales Bill, the Assembly established a shadow Commission to plan for the Assembly's future and to oversee the final stages of administrative separation between the parliamentary and executive branches (Stirbu 2009). The Shadow Commission conducted significant work in relation to repositioning the Assembly (as a legislature) within the Welsh polity, with a separate identity from the (then) Welsh Assembly Government. During the same period (2006-2007), the Committee on the Standing Orders, another ad-hoc structure, designed the new internal procedures for the post-corporate body Assembly, thus redefining the power dynamics within the Welsh constitutional system.

The legislative-executive relationship represents an important source of institutionalisation and institutional autonomy of parliaments around the world (Olson and Crowther 2002) since it is normally indicative of institutional maturity (Norton 1998; Olson and Crowther 2002). Yet, existing scholarship is mostly silent on hybrid - that is, blurred lines between legislative and executive functions - and emerging institutions (like the Assembly) that operate within extremely fluid constitutional contexts and experience gradual accrual of powers. The Assembly's constitutional journey is to some degree one of normalising this relationship, first within the context of the corporate body and, later, set against separation and enhanced legislative powers. 
The Assembly committee system's evolution has reflected this journey to a great extent, from subtle, yet powerful changes in the way committees separated meeting in scrutiny and policy mode during the corporate body, to the reconfiguration of committees along broad cross cutting themes rather than mirroring ministerial portfolios.

Institutionalisation is a process that requires time, consolidation of practice, dissemination of values and continuity of structures (Patterson and Copeland 1994). Whereas the Shadow Commission represented a first instance of strategic corporate leadership shaping the Assembly's constitutional vision, the Committee on Standing Orders created the first real platform for the Assembly to design its internal structure and operations, thus signalling a qualitative move from implementation of constitutional provisions to principal agent of change. This is further evidenced by the establishment of other ad-hoc committees that scrutinised constitutional and legislative proposals affecting Wales: the Committee on the Better Governance for Wales White Paper (in 2005), and the Committee on the Government of Wales Bill (in 2006). Nonetheless, despite some evidence of functional differentiation, these were ad-hoc, temporary structures.

Post 2007, we note a more rapid pace in embedding constitutional affairs and procedural change within permanent structures in the committee system. For instance, revising the internal procedures became the responsibility of the Business Committee, a permanent and influential structure in the Assembly, benefitting from a relatively stable membership. The Constitutional Affairs Committee ${ }^{5}$, established in the third term, is another permanent structure, built on the legacy of the former (secondary) Legislation Committee that has seen its portfolio enhanced to scrutinising constitutional issues arising from the fluid nature of devolution in Wales. The Committee's work on the pre-legislative scrutiny of the Draft Wales Bill in 2015, alongside that of the Welsh Affairs Select Committee's at Westminster, was critical in ensuring the Secretary of

\footnotetext{
${ }^{5}$ Constitutional and Legislative Affairs Committee in the 5th term
}

Page 20 
State for Wales reconsidered its approach to shaping Wales' next constitutional settlement and addressed a series of major concerns raised in the process (BBC News, 29 February 2016).

Similarly, the Assembly Commission became the main forum for strategic corporate thinking and forward planning, and continues to play an important role in the process of resource allocation (Assembly Commission 2013) and in ensuring the Assembly's strategic fit within the changing constitutional context (Assembly Commission, 2015). The Presiding Officer recently undertook forward planning around anticipated changes from the Wales Act 2017, and significantly, has led proposals for reform of the electoral system, the size and capacity of the Assembly and Votes at 16, in the light of the devolution of electoral matters to the Assembly (National Assembly for Wales, 1 February 2017).

The evidence presented here points to significant shifts in the way the Assembly has positioned itself within the constitutional arena. We notice the more established and standardised manner for responding to constitutional change in the third, fourth and fifth terms, as opposed to the less institutionalised way in which the Assembly operated prior to 2007.

\section{Micro-level: Organisational stability, continuity and autonomy}

At micro-level, we focus on the maturing of committees from an organisational perspective. We are especially interested in the evolution of structural attributes of the committee system, such as number, size, permanence of committees, and membership characteristics (incumbency, turnover) across the four terms, thus exposing the degree of stability and continuity. The extent to which the committee system achieved a relative autonomy from the rest of the Assembly is also relevant. 
The committee model remained largely unchanged in the first two terms in terms of number, type, size of committees and their relationship with the rest of the Assembly. The only structural volatility is the number of ad-hoc committees established, a stark contrast between two in the first term, and ten in the second. This was largely accounted for the institutional response to a heavy constitutional flux generated by the re-election of a Labour Government and its Welsh devolution plans ${ }^{6}$, and to more intense legislative activity concerning Wales at Westminster, which required scrutiny from the Assembly. The relative stability of the corporate body committee model should be attributed more to the constraining legislative framework than to anything else.

The number of committees was drastically streamlined, from 32 in second term to 12 in the fourth term. Membership and size rules themselves changed from being strict and prescribed ${ }^{7}$ (see Table 2) during the corporate body, to allowing more flexibility in the fourth term. In the context of the small Assembly size (60 members), the number of committees and their membership is critical, giving the strain on individual Members' workload. Multiple memberships in committees has been one of the hindrances to effective scrutiny in the first term (McAllister and Stirbu 2007a) and although this has improved in the fourth term, it remains the highest in the UK legislatures: during the fifth term there are 44 Members and 83 committee roles to fill (EPAER, 2017). Thus far, the capacity issue has been mitigated via institutional engineering: committees of variable size, streamlining the number of committees and their portfolios, more effective use of subcommittees and rapporteurs.

Other measures of committee institutionalisation focus on their relationship with the rest of the Assembly and on their legislative autonomy. On both of these measures, the committees provide

\footnotetext{
${ }^{6}$ Committee on the Better Governance for Wales (2005-2007), the Shadow Commission (2006-2007), Committee on the Standing Orders (2005-2007), Committee on the Government for Wales Bill (2006)

${ }^{7}$ To reflect the overall party balance in the Assembly
}

Page 22 
evidence of steady maturing and consolidation. Committee autonomy can be hindered by excessive party control over committee members and by attempts to minimise dissent -this possibly explaining the high turnover in committee membership in the first term. More specific to the Assembly was the executive dominance in the corporate body period due to ministerial membership in subject committees. For example, committees portfolio changes usually reflected reshuffles on the executive side (e.g. agriculture and rural development portfolio changed to environment, planning and countryside in the second term). Since 2007, when the Assembly started operating de facto as a parliament, committees can amend bills (at committee stage) and have legislative initiative, which they have used successfully on three occasions (Committee on Standards of Conduct with one legislative initiative in the third term and the Commission with two initiatives- admittedly, all on internal matters rather than wider public policy). The recasting of committee portfolios in the third and fourth terms suggests a more deliberate and planned attempt to naturally realign some policy priorities (e.g. children and young people with education; environment with sustainability etc).

The transformation of the committee system at organisational and operational level reflects, to a great extent, the development of Welsh devolution. It maps all of its significant landmarks: the overly prescribed, limited and executive-driven corporate body, the complexity of the interim constitution which led to the more consolidated stage of primary powers, all underpinned by the struggle to balance the small size and capacity with an expanding portfolio of power and competencies. A significant finding here is the role of strategic management in mitigating, or addressing (when within its powers) the capacity issue of the Assembly, a leitmotif of Welsh devolution. Overall, the committees' evolution has largely been from novelty, peculiarity, and experimentation to absorbing traditional and more widely established parliamentary norms and practices. 


\section{Conclusion}

This chronicling of the Assembly committees and their development underlines the consolidation of stable and predictable patterns of organisation, operation and responsiveness to change. Taken as a whole, we find that the committees encapsulate devolution's most prominent rhetorical strand, that of closer engagement with citizens framed by a more open and accessible politics. This approach characterised the operation of the policy-oriented committees, via some interesting experimentation, in the first two Assemblies, but with little standardisation of consultative and engagement practices. As the Assembly matured, so public engagement became more entrenched at strategic level and functionally and organisationally differentiated via permanent structures such as the Petitions' Committee or via the newly integrated committee support services. Our analysis has highlighted the strong correlation between devolution's inclusive rhetoric and its transposition in organisational structures and processes.

Secondly, we consider committees to be a useful device for understanding the wider change process, initially by innovative adaptation and reconfiguration of structures (institutional engineering), and later by becoming active and more autonomous deliberators and scrutinisers of wider constitutional shifts around them. As the Assembly acquired more traditional parliamentary structures such as the Commission and the Business Committee, constitutional considerations became more embedded at committee level and were given elevated attention through better scrutiny and oversight.

The micro level of the Aston Matrix also helped map the extent to which the committees have achieved stable patterns of organisation, membership, permanence and autonomy with respect to the rest of the Assembly. At this level, we found a higher degree of predictability throughout the fourth Assembly, some radical changes in the committee system in the third term, and a relatively higher instability of the committee system in the first two Assemblies between 1999 
and 2007. There was also a significant change in terms of the statutory framework regarding their organisation, ranging from highly prescribed to more flexible as the institution matured. The structural changes in the committees in the third and fourth Assemblies are indicative of their more strategic management by the Commission, a stronger focus on scrutiny, and a larger and institutionalised emphasis on public engagement. The establishment of the Assembly Commission ensured that strategic leadership was formalised, with a clear outline of the role that committees were expected to play within the broader institutional strategy.

Overall, our analysis reveals a close relationship between the Assembly's internal committee system and processes, and the wider strategic operating context. The committees have actively shaped the Assembly's internal configuration and procedures, whilst also informing and contributing to broader constitutional debates, especially through driving greater public engagement.

This article offers a different take on the typical journey of change and adaptation within a democratic institution. In focusing exclusively on committees in a new institution, a rarely used area of internal architecture for such research, it has_explored the process of institutional change. The paper's contribution is twofold: first, by fusing management analysis and political theory in its conceptual approach, it has allowed for a different and more forensic analysis of the markers for change. Secondly, and uniquely we believe, it has focused upon changes in committee profile and identity, suggesting a role for them as significant reflectors of constitutional change. This hybrid theoretical framework offers insight into how a parliamentary organisation strategically manages and resources its deliberative practices, essential to positioning the institution within its wider polity.

Whilst committees have been primarily evidenced as markers of change, our study also hints at a further perspective and a somewhat deeper level of analysis. It is too early to offer a conclusive 
verdict on the impact of committees as determinants of the change process as this will require further longitudinal and comparative studies. However, we can say that the development of ancillary studies of committees is a positive and complementary addition to the wider study of constitutional change, especially during periods of significant institutional flux. The Assembly committees have clearly reflected the pace and shape of changes in devolution, as well as reflecting ongoing constitutional debate on devolution itself.

Page 26 


\section{References}

Ágh, A. (1998). Changing parliamentary committees in changing east-central Europe: Parliamentary committees as central sites of policy making. The Journal of Legislative Studies, $4(1), 85-100$.

Arter, D. (2002). On assessing strength and weakness in parliamentary committee systems: some preliminary observations on the new Scottish Parliament. Journal of Legislative Studies, 8(2), 93-117.

Arter, D. (2004). The Scottish committees and the goal of a 'New Politics': a verdict on the first four years of the devolved Scottish parliament. Journal of Contemporary European Studies, 12(1), 71-91.

Arter, D. (2006). From 'spectator democracy' to 'inclusive democracy'? The peripatetic Scottish committees as linkage. Regional and Federal Studies, 16(3), 239-262.

Assembly Commission, (2007). National Assembly for Wales Strategy 2007-2011, Cardiff: National Assembly.

Assembly Commission (2011). National Assembly Strategy 2011-2016, Cardiff: National Assembly.

Assembly Commission (2013). Review of Support for Committees, URL: http://tinyurl.com/h8etllt. 
Assembly Commission (2015). The Future of the Assembly: ensuring its capacity to deliver for Wales, URL: http://tinyurl.com/hode8he.

BBC News (2016). Wales Bill needs significant changes, Stephen Crabb says, 29 February 2016, URL: http://www.bbc.co.uk/news/uk-wales-politics-35685623.

Bochel, C. (2013). Petitions systems: contributing to representative democracy?. Parliamentary Affairs, 66(4), 798-815.

Bradbury, J. and Mawson, J. (2014). British regionalism and devolution: the challenges of state reform and european integration. Routledge.

Brazier, A., Flinders, M. V., \& McHugh, D. (2005). New Politics, New Parliament?: A Review of Parliamentary Modernisation Since 1997. Hansard Society.

Brown, K., \& Osborne, S. P. (2012). Managing change and innovation in public service organizations. Routledge.

Cairney, P. (2006). The analysis of Scottish Parliament committee influence: Beyond capacity and structure in comparing West European legislatures. European Journal of Political Research, 45(2), 181-208.

Carter, C. A. (2013). Rethinking UK parliamentary adaptation in EU affairs: devolution and Europeanisation. The Journal of Legislative Studies, 19(3), 392-409.

Page 28 
Chaney, P., \& Fevre, R. (2001). Inclusive governance and "minority" groups: the role of the third sector in Wales. Voluntas: International Journal of Voluntary and Nonprofit Organizations, $12(2), 131-156$.

Cole, M., McAllister, L., \& Stirbu, D. (2013). The capacity of the National Assembly. A Stable, Sustainable Settlement for Wales, 6-17.

Cole, M. (2014). Devolution and the enhancement of scrutiny: A case study of the committees of the National Assembly for Wales. Public Policy and Administration, 29(1), 3-20.

Cole, M., \& McAllister, L. (2015). Evaluating and theorising committee scrutiny: A UK comparative perspective. Local Government Studies, 41(2), 220-239.

Curtice, J. (2013). Politicians, voters and democracy: The 2011 UK referendum on the Alternative Vote. Electoral Studies, 32(2), 215-223.

Damgaard, E. (1995). How parties control committee members. Parliaments and majority rule in Western Europe, 308, 25.

Day, G. (2006). Chasing the dragon? Devolution and the ambiguities of civil society in Wales. Critical Social Policy, 26(3), 642-655.

Döring, H. (Ed.). (1995). Parliaments and majority rule in Western Europe(pp. 223-46). Frankfurt: Campus.

Döring, H. (2001). Parliamentary agenda control and legislative outcomes in Western Europe. Legislative Studies Quarterly, 145-165. 
Drewry, G. (1985). The New Select Committees: A study of the 1979 reforms.

Elcock, H., \& Keating, M. (Eds.). (2013). Remaking the Union: devolution and British politics in the 1990s. Routledge.

Elliott, M. (2015). The Principle of Parliamentary Sovereignty in Legal, Constitutional, and Political Perspective. In Jowell et al. The Changing Constitution, 38.

Flinders, M. (2002). Shifting the balance? Parliament, the executive and the British constitution. Political Studies, 50(1), 23-42.

Gifford, C. (2010). The UK and the European Union: dimensions of sovereignty and the problem of Eurosceptic Britishness. Parliamentary Affairs, 63(2), 321-338.

GoWA,1998, Government of Wales Act, London: HMSO.

GoWA, 2006, Government of Wales Act, London: HMSO.

Griffiths, S., \& Evans, P. (2013). Constitution by Committee? Legislative Competence Orders under the Government of Wales Act (2007-2011). Parliamentary Affairs, 66(3), 480-510.

Hansard Society (2010). Audit of political engagement 7. The 2010 Report: With a Focus on MPs and Parliament, URL: http://tinyurl.com/zmjvjib.

Hazan, R. Y. (2003). Introduction: Does cohesion equal discipline? towards a conceptual delineation. The Journal of Legislative Studies, 9(4), 1-11. 
Hough, R. (2012). Do legislative petitions systems enhance the relationship between parliament and citizen?. The Journal of Legislative Studies, 18(3-4), 479-495.

House of Lords Constitution Committee, 1st Report (2001-2002): Reviewing the Constitution: Terms of Reference and Method of Working (HL Paper 11), para 20.

House of Lords Constitution Committee (2011), Fifteenth Report - The Process of Constitutional Change, URL: https://tinyurl.com/k52v6ey.

Huntington, S. P. (2006). Political order in changing societies. Yale University Press.

Kelly, R. (2013). 'Select Committees: Powers and Functions', in Horne et al. Parliament and the Law, AC \& Black.

Kim, D. H., \& Loewenberg, G. (2005). The Role of Parliamentary Committees in Coalition Governments Keeping Tabs on Coalition Partners in the German Bundestag. Comparative Political Studies, 38(9), 1104-1129.

Laycock, S. (2013). Is referendum voting distinctive? Evidence from three UK cases. Electoral Studies, 32(2), 236-252.

Leston-Bandeira, C. (2012). Studying the relationship between Parliament and citizens. The Journal of Legislative Studies, 18(3-4), 265-274

Leston-Bandeira, C. (2016). Why symbolic representation frames parliamentary public engagement. The British Journal of Politics and International Relations, 18(2), 498-516.

Page 31 
Longley, L.D. eds. (1994). Working papers on comparative legislative studies. International Political Science Association. Research Committee of Legislative Specialists.

Longley, L.D. \& Agh, A. eds. (1997). Working papers on the changing roles of parliamentary committees. International Political Science Association. Research Committee of Legislative Specialists.

Mattson, I., and Strøm, K. (1995). Parliamentary Committees 1. Parliaments and majority rule in Western Europe, 249.

McAllister, L., \& Kay, A. (2010). Core tensions in Wales's new politics: pluralist trends in a majoritarian system. Public Money \& Management, 30(2), 103-108.

McAllister, L. and Stirbu, D.S. (2007a) - 'Opportunities for Gender Innovations in a New Political Space', The International Journal of Interdisciplinary Social Sciences, 1, CG Publisher.

McAllister, L. and Stirbu, D.S. (2007) - 'Developing Devolution's Scrutiny Potential: A Comparative Evaluation of the National Assembly for Wales's Subject Committees', Policy and Politics, 35(2), 289-309.

McAllister, L., \& Stirbu, D. S. (2008). Influence, impact and legacy-assessing the Richard Commission's contribution to Wales's evolving constitution. Representation, 44(3), 209-224.

McAllister, L. (2005). The Value of Independent Commissions: An Insider's Perspective on the Richard Commission. Parliamentary Affairs, 58(1), 38-52. 
McLaverty, P., and MacLeod, I. (2012). Civic Participation in the Scottish Parliament Committees. International Journal of Public Administration, 35(7), 458-470.

National Assembly for Wales (2017) Press release, 1 February 2017, URL: https://tinyurl.com/k3gozs2.

Norton, P. (1998). Nascent institutionalisation: Committees in the British parliament. The Journal of Legislative Studies, 4(1), 143-162.

Norton, P. (2000). Reforming parliament in the United Kingdom: the report of the Commission to Strengthen Parliament. The Journal of Legislative Studies, 6(3), 1-14.

Olsen, J. P., and March, J. G. (2004). The logic of appropriateness (No. 9). ARENA.

Olson, D. M., \& Crowther, W. E. (2002). Committees in Post-Communist Democratic Parliaments: Comparative Institutionalization. Ohio State University Press.

Patterson, S. C., \& Copeland, G. W. (1994). Parliaments in the Twenty-first Century. Parliaments in the Modern World, 1-11.

Petitions Committee (2016). Review of the Petitions Arrangement, URL: https://tinyurl.com/k43lmct

Pollack, M. A. (2003). Control mechanism or deliberative democracy? Two images of comitology. Comparative Political Studies, 36(1-2), 125-155.

Porter, M.E., (1996). What is Strategy?. Harvard Business Review Nov-Dec, 61-78. 
Richard Commission (2004). Report of the Richard Commission: Commission on the powers and electoral arrangements of the National Assembly for Wales, Stationery Office.

Rumbul, R. (2016). Gender Inequality in Democratic Participation: Examining Oral Evidence to the National Assembly for Wales. Politics, 36(1), 63-78.

Russell, M. (2011). 'Never Allow a Crisis Go To Waste': The Wright Committee Reforms to Strengthen the House of Commons. Parliamentary Affairs, 64(4), 612-633.

Scully, R., \& Wyn Jones, R. (2015). The Public Legitimacy of the National Assembly for Wales. The Journal of Legislative Studies, 21(4), 515-533.

Stirbu, D.S. (2009) - 'Instituting Constitutions: The Internal Reconfiguration of the National Assembly for Wales from 2005 to 2007', Contemporary Wales, 22, 95-112.

Strøm, K. (1998). Parliamentary committees in European democracies. The Journal of legislative studies, 4(1), 21-59.

Page 34 


\section{Biographical notes}

Diana Stirbu is Senior Lecturer in Public Administration at London Metropolitan University, and an expert on devolution. Diana obtained her PhD at the University of Liverpool after graduating the Liverpool MPA programme with Distinction. Diana specialises in territorial politics, parliamentary studies and strategic management in the public sector. Diana contributes regularly to constitutional debates in England and Wales in expert or advisory capacity.

Laura McAllister is Professor of Public Policy and the Governance of Wales at Cardiff University's Wales Governance Centre. Laura was a member of the Richard Commission on the Powers and Electoral Arrangements for National Assembly for Wales and a member of the National Assembly Remuneration Board. She was Chair of the Presiding Officer's Expert Panel on Electoral Reform, which reported in December 2017. 